\title{
SUPPLEMENTATION WITH 0.1\% AND 2\% VITAMIN E IN DIABETIC RATS: analysis of myenteric neurons immunostained for myosin-V and nNOS in the jejunum
}

\author{
Eleandro Aparecido TRONCHINI, Aline Rosa TREVIZAN, Cristiano Massao TASHIMA, \\ Renata Virginia Ferreira PEREIRA and Jacqueline Nelisis ZANONI
}

\begin{abstract}
Context - Diabetes mellitus is a disease characterized by hyperglycemia that, when allowed to progress long-term untreated, develops vascular and neurological complications, which are responsible for the development of alterations in the enteric nervous system in diabetic patients. In the gastrointestinal tract, diabetes mellitus promotes motor and sensory changes, and in the reflex function of this system, causing gastroparesis, diarrhea, constipation, megacolon, slow gastrointestinal transit, gastric stasis and dilation with decreased or increased peristaltic contractions. Several studies have shown that oxidative stress is the main responsible for the vascular and neurological complications affecting the enteric nervous system of diabetics. Objective - The effects of $0.1 \%$ and $2 \%$ vitamin E on myosin- $\mathrm{V}$ - and nNOS-immunoreactive neurons in the jejunum of diabetic rats were investigated. Methods - Thirty rats were divided into the groups: normoglycemic, normoglycemic treated with $0.1 \%$ vitamin E, normoglycemic treated with $2 \%$ vitamin $\mathrm{E}$, diabetic, diabetic treated with $0.1 \%$ vitamin $\mathrm{E}$, and diabetic treated with $2 \%$ vitamin $\mathrm{E}$. The neuronal density and areas of neuron cell bodies were determined. Results - Diabetes (diabetic group) significantly reduced the number of myosin-V-immunoreactive neurons compared with the normoglycemic group. The diabetic treated with $0.1 \%$ vitamin $\mathrm{E}$ and diabetic treated with $2 \%$ vitamin E groups did not exhibit a greater density than the $\mathrm{D}$ group $(P>0.05)$. Nitrergic density did not change with diabetes $(P>0.05)$. The areas of myosin-V- and nNOS-immunoreactive neurons significantly increased in the normoglycemic treated with $2 \%$ vitamin $\mathrm{E}$ and diabetic groups compared with the normoglycemic group. Conclusion - Supplementation with 2\% vitamin E had a neurotrophic effect only in the area of myosin-V-immunoreactive neurons compared with the diabetic group.
\end{abstract}

HEADINGS - Vitamin E. Diabetes mellitus, experimental. Jejunum. Neurons. Myosin type V. Nitric oxide sinthase. Rats.

\section{INTRODUCTION}

Diabetes mellitus (DM) is an endocrine-metabolic disorder characterized by chronic hyperglycemia. When allowed to progress long-term untreated, this disorder can develop complications such as microangiopathy (retinopathy, nephropathy, and neuropathy) and macroangiopathy (atherosclerosis) ${ }^{(7)}$. Among the chronic complications, neuropathies are the most common and can affect the autonomic nervous system, including the cardiovascular system, gastrointestinal tract, and

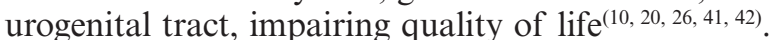
Recent studies have shown that diabetic neuropathy may impair enteric neurons in the autonomic nervous system, causing diarrhea, constipation, nausea, emesis, abdominal pain, and flatulence ${ }^{(8,16,29)}$.

The enteric nervous system consists of a network of neurons that are responsible for the control of mucus secretion, intestinal motility, and local blood circulation. This neuronal network also modulates immune and endocrine function and is found mainly in the myenteric plexus (Auerbach plexus) and submucosal plexus (Meissner plexus) ${ }^{(16)}$. Such tissues may be damaged or modified by diabetic neuropathy through various mechanisms, including disturbances in the polyol pathway, the formation of advanced glycosylation end-products (AGEs) ${ }^{(9,29,35)}$, and oxidative stress ${ }^{(19,37,40)}$. These mechanisms together lead to free radical production and a decrease in various antioxidant defenses, such as glutathione (GSH), ascorbic acid (vitamin C), and $\alpha$-tocopherol (vitamin E) ${ }^{(30,38)}$. Among these, vitamin $\mathrm{E}$ has been shown to be neuroprotective because of its antioxidant function against oxidative stress in cells. 
Vitamin $\mathrm{E}$ is deposited in lipid cell membranes because of its liposoluble characteristics, thus forming a complex with phospholipids, increasing the viscosity and facilitating the union of polyunsaturated fatty acids, thereby increasing membrane stability. Moreover, vitamin E interferes with lipid peroxidation and inhibits the enzyme phospholipase A2, thus preventing membrane phospholipid hydrolysis $(15,31,36,43,45)$.

The present study investigated the effects of vitamin E supplementation at different concentrations $(0.1 \%$ and $2 \%$ ) on the general population of myenteric neurons (myosin-V-immunoreactive) and on the subpopulation of nitrergic neurons (neuronal nitric oxide synthase [nNOS]-immunoreactive) in the jejunum of rats with DM.

\section{METHODS}

\section{Animal procedures}

All of the procedures of the present study were performed in accordance with the ethical principles of the Federal Law 11.794 (October 2008) and Decree 66689 (July 2009) dictated by the Brazilian Society of Animal Science Laboratory (SBCAL) and revised and approved by the Committee of Ethics in Animal Experimentation of the State University of Maringá.

The present study used 30 male Wistar rats (Rattus norvegicus) from the Central Animal House of the State University of Maringá. The animals were divided into six groups: normoglycemic (UN), normoglycemic treated with $0.1 \%$ vitamin E (NE1), normoglycemic treated with $2 \%$ vitamin E (NE2), diabetic (UD), diabetic treated with $0.1 \%$ vitamin E (DE1), and diabetic treated with $2 \%$ vitamin E (DE2).

At the age of 90 days, the rats were housed in polypropylene boxes for 120 days under a $12 \mathrm{~h} / 12 \mathrm{~h}$ light/dark cycle (lights off 06:00-18:00) and controlled temperature $\left(24 \pm 2^{\circ} \mathrm{C}\right)$ with free access to food and water. The non-supplemented animals ( $\mathrm{N}$ and $\mathrm{D}$ groups) were fed the standard balanced chow Nuvital ${ }^{\mathbb{B}}$ (Nuvilab, Colombo, PR, Brazil). The NE and DE groups had vitamin E (Zhejiang NHU, China) added to the standard chow at concentrations of $0.1 \%\left({ }^{(37)}\right.$ and $2 \%(23)$.

Diabetes mellitus was induced in the animals from the UD, DE1, and DE2 groups after $14 \mathrm{~h}$ of fasting through intravenous injection of streptozotocin $(35 \mathrm{mg} / \mathrm{kg}$ body weight; Sigma, St. Louis, MO, USA) dissolved in citrate buffer, $\mathrm{pH}$ $4.5(10 \mathrm{mM})$. After DM induction, glycemia was determined through glucose oxidase measurements to ascertain the establishment of the experimental model ${ }^{(6,18)}$. All animals in the UD and DE groups exhibited glycemia $>250 \mathrm{mg} / \mathrm{dL}$.

\section{Material collection and processing}

On day 120 of the experiment, the animals were sacrificed after being weighed and anesthetized with $40 \mathrm{mg} / \mathrm{kg}$ of intraperitoneal thiopental (Abbott Laboratories, Chicago, IL, USA). Blood was collected through cardiac puncture to determine plasma glucose and glycated hemoglobin levels (ion-exchange resin method). The jejunum from 30 animals ( 5 from each experimental group) was collected and processed using the myosin- $\mathrm{V}$ nNOS immunohistochemistry technique.

\section{Immunolocalization of neuronal myosin-V: study of general myenteric neuron population}

The animals were perfused with cold $1.1 \%$ saline solution, followed by fixative solution containing $10 \mathrm{mM}$ sodium periodate, $75 \mathrm{mM}$ lysine, and 1\% paraformaldehyde in $37 \mathrm{mM}$ phosphate buffer, $\mathrm{pH} 7.4^{(21)}$. Immediately after perfusion, the jejunum was resected, washed with saline solution until complete removal of feces, carefully inflated with the fixative solution such that the segments were not distended, and tied at the ends with cotton thread. After this procedure, the tissue was maintained in fixative solution for $1 \mathrm{~h}$, dehydrated in an ascending series of alcohol $(50 \%, 70 \%, 80 \%, 90 \%$, and $100 \%$ ), clarified in xylol, and rehydrated in a decreasing series of alcohol $(100 \%, 95 \%, 90 \%, 80 \%$, and $70 \%)$. The jejunum was dissected with the aid of a trans-illumination stereomicroscope to obtain whole-mount muscular layer preparations through the removal of the mucousal and submucousal layers. Whole-mount preparations were then subjected to a technique for the detection of myosin- $\mathrm{V}$-immunoreactive myenteric neurons.

The preparations were washed four times in $0.1 \mathrm{M}$ phosphate-buffered saline (PBS), $\mathrm{pH} 7.4$, and blocked for $1.5 \mathrm{~h}$ in PBS solution containing $2 \%$ bovine serum albumin (BSA; Sigma), goat serum (1:50), and 0.5\% Triton X-100 (Sigma) at room temperature. The preparations were then sequentially incubated for $48 \mathrm{~h}$ in PBS solution containing the polyclonal primary antibody anti-myosin- $\mathrm{V}$ (extracted from rabbit; 1:750; Universidade de São Paulo, Ribeirão Preto, SP, Brazil), 1\% BSA, goat serum (1:50), and 0.5\% Triton X-100 at room temperature under agitation. After incubation, the preparations were washed twice in PBS solution with $0.1 \%$ Triton X-100 and twice in PBS solution with $0.05 \%$ Tween-20. The tissue was then incubated with anti-rabbit secondary antibody (1:1000) conjugated with $1 \mu \mathrm{g} / \mathrm{mL}$ peroxidase (Pierce, Rockford, IL, USA) for $24 \mathrm{~h}$ at room temperature. Finally, the tissue was washed four times with PBS solution with $0.05 \%$ Tween-20. The immunoreaction was revealed by diaminobenzidine (DAB; Sigma), and the preparations were mounted in glycerol gel. A negative control was performed with the omission of the primary antibody.

\section{Immunolocalization of nNOS: study of nitrergic myenteric neuron population}

After the animals were sacrificed, their jejunums were resected, washed in 0.1 M PBS, pH 7.4, inflated with Zamboni fixative, and maintained for $18 \mathrm{~h}$ in the same solution. Afterward, the segments were cut along the mesenteric border and successively washed in $80 \%$ alcohol until the visible removal of the fixative. The preparations were dehydrated in alcohol (95\% and $100 \%$ ), clarified in xylol, rehydrated in a decreasing series of alcohol $(100 \%, 90 \%, 80 \%$, and $50 \%)$, and immersed in PBS. The segments were then dissected to obtain whole-mount muscular layer preparations. The preparations were then subjected to an immunohistochemistry technique for the detection of nitrergic myenteric neurons.

The preparations were initially washed 3 times in PBS solution with $0.5 \%$ Triton X-100 and incubated in $1 \%$ BSA 
in PBS for $1 \mathrm{~h}$. After being blocked, the tissues were incubated for $48 \mathrm{~h}$ at room temperature in primary antibody specific for nNOS (1:500; Santa Cruz Biotechnology, Santa Cruz, CA, USA). The tissues were washed 3 times in PBS and incubated with anti-rabbit secondary antibody (1:400; Santa Cruz Biotechnology, Santa Cruz, CA, USA) for $2 \mathrm{~h}$ at room temperature. Afterward, the preparations were successively washed 3 times in PBS. Finally, the preparations were incubated with avidin-biotin-peroxidase $\mathrm{ABC}$ complex $(1: 1500)$ for $1 \mathrm{~h}$. The immunoreaction was revealed by DAB containing $0.02 \% \mathrm{H}_{2} \mathrm{O}_{2}$, and the preparations were mounted in glycerol gel. A negative control was performed with the omission of the primary antibody.

\section{Quantitative analysis of myosin-V- and nNOS- immunoreactive myenteric neurons}

Quantification of myosin- $\mathrm{V}$ - and nNOS-immunoreactive myenteric neurons was performed using images obtained randomly from the intermediate $\left(60^{\circ}-120^{\circ}, 240^{\circ}-300^{\circ}\right)$ intestinal circumference from each animal, with $0^{\circ}$ considered the mesenteric insertion. The images were captured by an AxioCam high resolution camera (Zeiss, Jena, Germany) coupled to an Axioskop Plus light microscope (Zeiss), digitized using AxioVision version 4.1 software, and recorded onto compact disc. The images analysis software Image-Pro Plus version 4.5.0.29 (Media Cybernetics, Silver Spring, MD, USA) was used for the neuronal quantification of the images recorded onto computer disk.

For each animal, all neurons present in 26 images, captured at 20X magnification, were counted. The area of each image, measured using Image-Pro Plus, was approximately $0.215 \mathrm{~mm}^{2}$. Results are expressed as the number of neurons per $\mathrm{cm}^{2}$

\section{Morphometric analysis of myosin-V- and nNOS- immunoreactive myenteric neurons}

Measurement of the areas of myosin-V- and nNOS-immunoreactive myenteric neuron cell bodies was performed using the same images, captured at 20x magnification. The area $\left(\mu \mathrm{m}^{2}\right)$ of 100 neuronal cell bodies was measured using Image-Pro Plus for each animal for each technique, yielding up to 500 areas per group.

\section{Statistical analysis}

Data were analyzed using Statistica 7.1 and GraphPad Prism 5.1 software and are expressed as mean \pm standard error (SE). The morphometric data were analyzed by block delineation followed by the Tukey test. All other data were analyzed using one-way analysis of variance (ANOVA) followed by the Tukey post hoc test. Values of $P<0.05$ were considered statistically significant.

\section{RESULTS}

The experimental model of diabetes was confirmed by glucose level determination, which remained above $250 \mathrm{mg} / \mathrm{dL}$. Diabetes mellitus reduced the number of myo-
sin-V-immunoreactive neurons by $28.23 \%$ in the UD group compared with the UN group $(P<0.05)$. Diabetic rats treated with vitamin $\mathrm{E}$ (DE1 and DE2 groups) had a $15.51 \%$ and $4.1 \%$ higher neuronal density, respectively, compared with the UD group $(P>0.05)$. Vitamin E supplementation $(0.1 \%$ and $2 \%$ ) did not alter neuronal density in normoglycemic animals $(P>0.05$; Figure 1$)$.

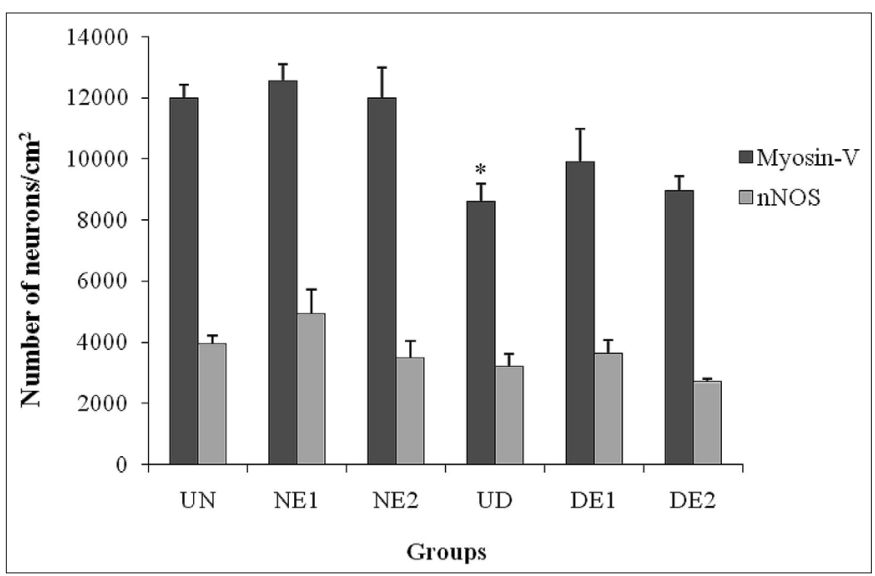

FIGURE 1. Density of myosin-V-and nNOS-immunoreactive myenteric neurons in $1 \mathrm{~cm}^{2}$ of the intermediate region of the jejunum in rats in the following groups: untreated normoglycemic (UN), normoglycemic treated with $0.1 \%$ vitamin E (NE1), normoglycemic treated with $2 \%$ vitamin $\mathrm{E}$ (NE2), untreated diabetic (UD), diabetic treated with $0.1 \%$ vitamin $\mathrm{E}$ (DE1), and diabetic treated with $2 \%$ vitamin E (DE2). Results are expressed as mean \pm standard error. $\mathrm{n}=5$ rats per group. $* P<0.05$, compared with the UN, NE1, and NE2 groups

The mean areas of myenteric neuron cell bodies immunoreactive to myosin- $\mathrm{V}$ are shown in Table 1 . A significant difference was observed between the UN and NE2 groups $(P<0.05)$, between the UN and UD groups $(P<0.05)$, and between the UD and DE2 groups $(P<0.05)$.

TABLE 1 . Cell body area (mean \pm standard error) of myosin-V- and nNOS-immunoreactive myenteric neurons

\begin{tabular}{lll}
\hline Group & Myosin-V $\left(\mu \mathrm{m}^{2}\right)$ & $\mathrm{nNOS}\left(\mu \mathrm{m}^{2}\right)$ \\
\hline UN & $260.0 \pm 4.5$ & $249.9 \pm 4.0$ \\
NE 1 & $244.2 \pm 3.5$ & $220,3 \pm 3.5^{*}$ \\
NE 2 & $494.9 \pm 6.6^{*}$ & $371.5 \pm 4.5^{*}$ \\
UD & $288.2 \pm 5.4^{*}, * *$ & $360.6 \pm 5.3^{*}$ \\
DE 1 & $288.2 \pm 5.2$ & $369.8 \pm 4.9$ \\
DE 2 & $494.6 \pm 7.2$ & $372.5 \pm 5.9$ \\
\hline
\end{tabular}

$\mathrm{UN}$, untreated normoglycemic; NE1, normoglycemic treated with $0.1 \%$ vitamin E; NE2, normoglycemic treated with $2 \%$ vitamin E; UD, untreated diabetic; DE1, diabetic treated with $0.1 \%$ vitamin E; DE2, diabetic treated with $2 \%$ vitamin E. Results are expressed as mean \pm standard error. $\mathrm{n}=5$ rats per group $* P<0.05$, compared with UN group; $* * P<0.05$, compared with DE2 group

Relative frequency determinations indicated that myosin-V-immunoreactive myenteric neuron cell body areas in the UN, NE1, UD, and DE1 groups ranged from 201 to 
$301 \mu \mathrm{m}^{2}$. The groups treated with $2 \%$ vitamin E (NE2 and DE2 groups) ranged from 401 to $701 \mu \mathrm{m}^{2}$ (Figure 2).

Nitrergic neuron density was not significantly different among groups $(P>0.05$; Figure 1$)$. The mean areas of nitrergic neuron cell bodies were significantly different between the UN and NE1 groups $(P<0.05)$, between the UN and NE2 groups $(P<0.05)$, and between the UN and UD groups $(P<0.05)$. Rats in the untreated diabetic group (UD group) were not significantly different from the treated diabetic groups (DE1 and DE2 groups; $P>0.05$; Table 1).

Relative frequency determinations indicated that nitrergic myenteric neuron cell body areas in the NE2, UD, DE1, and DE2 groups ranged from 250 to $450 \mu \mathrm{m}^{2}$, and the UN and NE1 groups ranged from 201 to $301 \mu \mathrm{m}^{2}$ (Figure 3).

\section{DISCUSSION}

In the present study, staining of myenteric neurons was performed using the myosin-V immunohistochemical technique. Diabetes mellitus significantly reduced the neuronal density of myosin-V-immunoreactive myenteric neurons in diabetic animals (D group) compared with normoglycemic

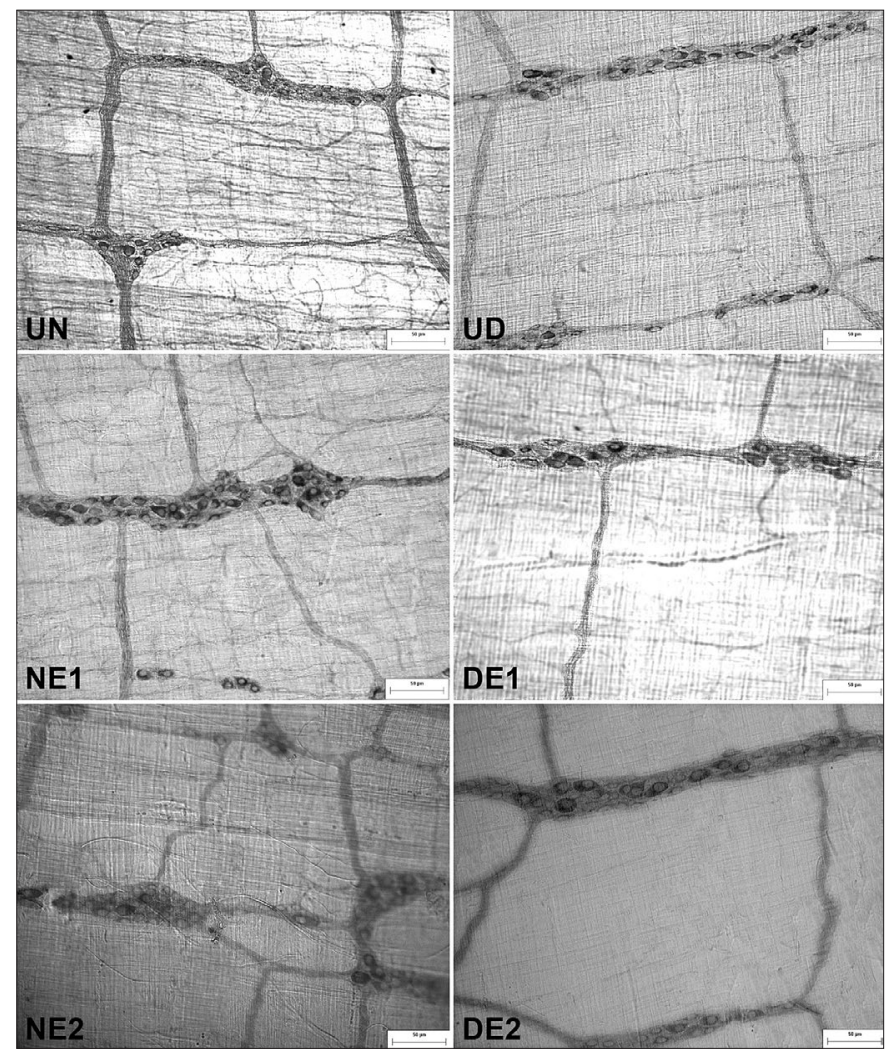

FIGURE 2. Micrographs of myosin-V-immunoreactive myenteric neurons of the intermediate region of the jejunum in rats in the following groups: untreated normoglycemic (UN), normoglycemic treated with $0.1 \%$ vitamin E (NE1), normoglycemic treated with $2 \%$ vitamin E (NE2), untreated diabetic (UD), diabetic treated with $0.1 \%$ vitamin $\mathrm{E}$ (DE1), and diabetic treated with $2 \%$ vitamin E (DE2). Calibration bar: $50 \mu \mathrm{m}$ animals. Similar results were found by Freitas et al. ${ }^{(12)}$, who observed a significant $37.9 \%$ reduction in neuronal density in the jejunum in diabetic animals compared with non-diabetic animals. Other studies performed by our group have analyzed different segments of the gastrointestinal tract, including the ileum ${ }^{(3,22,46)}$, proximal $\operatorname{colon}^{(15,24,25,34,39)}$, and stomach ${ }^{(14)}$ and showed similar results. This reduction in the number of myenteric neurons results from hyperglycemia, which initiates several biochemical events, such as disturbances in the polyol pathway, formation of AGEs, activation of the protein kinase $\mathrm{C}$ and hexosamine pathways, and glycolysis. These routes together produce high oxidative stress ${ }^{(39)}$. Thus, increased production of free radicals and a reduced capacity of the endogenous antioxidant defense system may be crucial for the occurrence of cellular death ${ }^{(5)}$. Moreover, the absence of insulin intensifies catabolic processes, disrupts ribosomal activity, and disrupts the synthesis and storage of proteins, leading to protein depletion, one of the most serious disorders in diabetic individuals ${ }^{(17)}$. These disorders contribute to neurological complications that may affect the autonomic and peripheral nervous systems ${ }^{(2,16)}$.

In normoglycemic animals (NE1 and NE2 groups), vita-

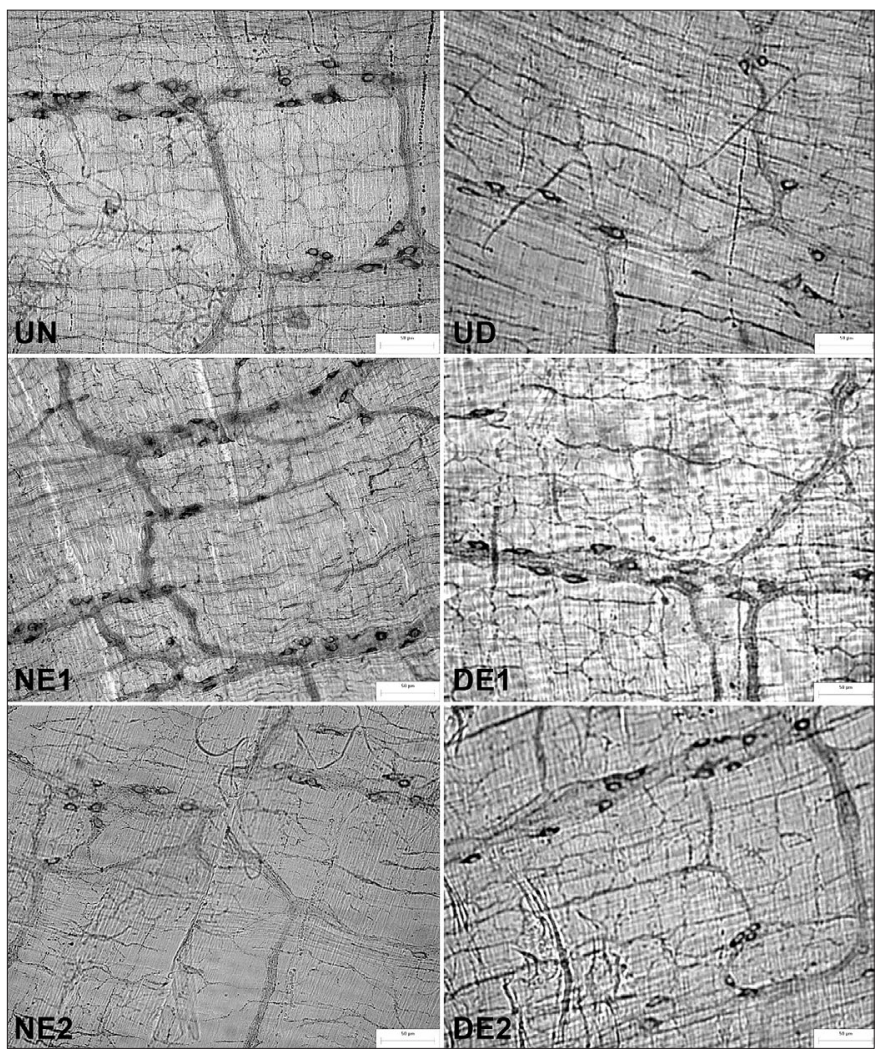

FIGURE 3. Micrographs of nNOS- immunoreactive myenteric neurons of the intermediate region of the jejunum in rats in the following groups: untreated normoglycemic (UN), normoglycemic treated with $0.1 \%$ vitamin E (NE1), normoglycemic treated with $2 \%$ vitamin E (NE2), untreated diabetic (UD), diabetic treated with $0.1 \%$ vitamin $\mathrm{E}$ (DE1), and diabetic treated with $2 \%$ vitamin E (DE2). Calibration bar: $50 \mu \mathrm{m}$ 
min E supplementation did not affect neuronal density. The DE1 and DE2 groups had $15.49 \%$ and $4.1 \%$ more myosin-V myenteric neurons, respectively, than diabetic animals (UD group), however these results were not significant. Pereira et al. ${ }^{(22)}$ when tested $0.1 \%$ vitamin $\mathrm{E}$ supplementation had similar results, ie, observed a $12 \%$ neuronal preservation $(P>0.05)$ in the ileum of supplemented diabetic animals.

Roldi et al. ${ }^{(24)}$ conducted studies on myenteric neurons from the proximal colon using the Giemsa method and observed a neuroprotective effect of vitamin $\mathrm{E}$ in the $2 \%$ concentration. This result is different of those found in the present study. Possible reasons for this discrepancy may be the differential effect of DM in different intestinal segments and differential endogenous antioxidant activity. Studies performed by Belai et al. ${ }^{(4,5)}$, demonstrated that the effect of $\mathrm{DM}$ occurs in different forms in each region of the intestine attributable to differences in the function and innervation of the myenteric plexus.

Cotter et al. ${ }^{(11)}$ also studied vitamin E $(1000 \mathrm{mg} / \mathrm{kg}$ body weight). They demonstrated prevention in the DM-induced

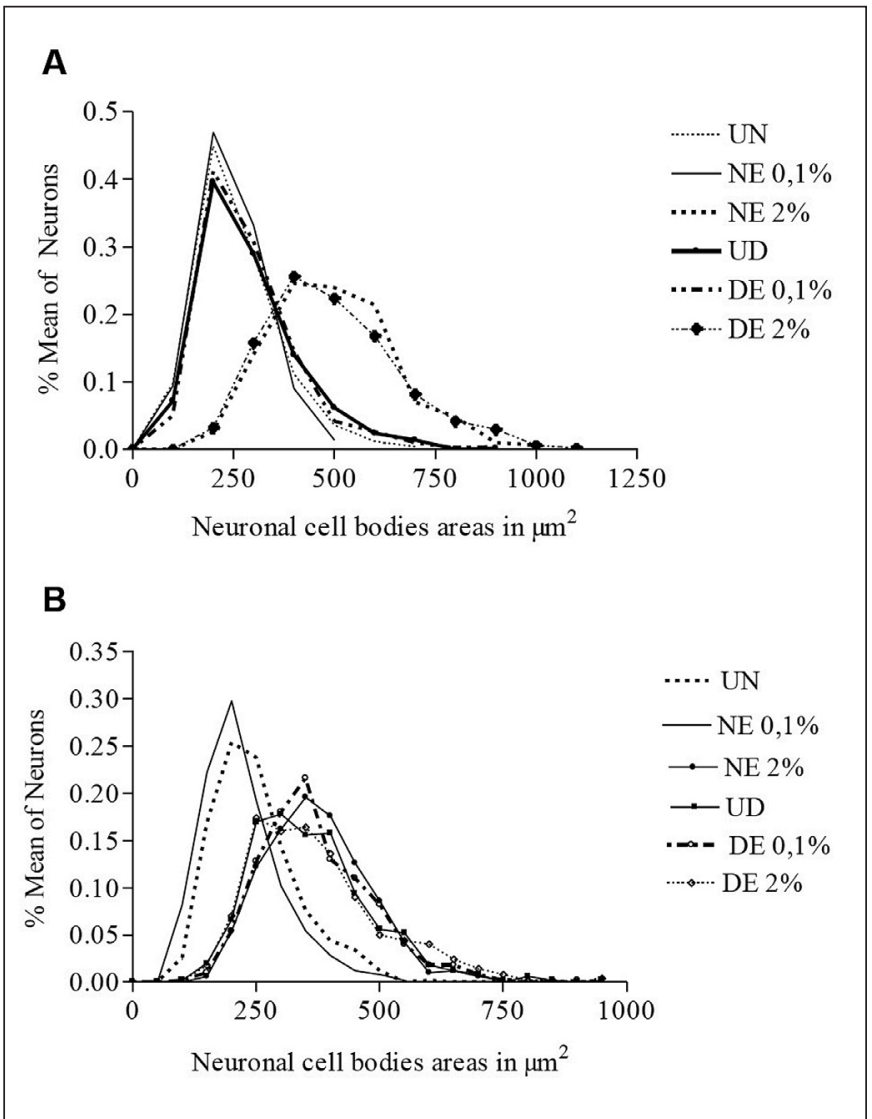

FIGURE 4. Relative frequency distribution of cell body area of (A) myosin-V-immunoreactive and (B) nNOS-immunoreactive myenteric neurons of the jejunum in rats in the following groups: untreated normoglycemic (UN), normoglycemic treated with $0.1 \%$ vitamin $\mathrm{E}$ (NE1), normoglycemic treated with $2 \%$ vitamin E (NE2), untreated diabetic (UD), diabetic treated with $0.1 \%$ vitamin $\mathrm{E}$ (DE1), and diabetic treated with $2 \%$ vitamin $\mathrm{E}(\mathrm{DE} 2) \cdot \mathrm{n}=5$ rats per group alterations in motor nerve conduction velocity. Moreover, they found that blood glucose levels and the consequent increase in free radicals in experimental diabetes are greater than in patients with controlled diabetes. We can infer that the neuroprotection of myosin-V-immunoreactive myenteric neurons in rats supplemented with vitamin $\mathrm{E}$ may be better if glycemia is controlled by administering insulin. However, glycemic control was not performed in the present study because such experimental design would not permit us to ascertain whether the results reflect supplementation with the antioxidant or blood glucose control.

By analyzing the area of myosin-V-immunoreactive myenteric neuron cell bodies, we found a significant $10.7 \%$ increase in the UD group compared with the UN group. Pereira et al. ${ }^{(22)}$ also found a $14 \%$ increase in the area of myosin-V-immunoreactive myenteric neuron cell bodies in the UD group compared with the UN group in the ileum of rats. The authors suggested that this increase in cell body area may occur because of changes in neuronal activity induced by DM. Treatment with vitamin $\mathrm{E}$ in the DE1 group did not alter cell body area compared with the UD group. However, a significant increase in cell body area was observed in the DE2 group compared with the UD group. A significant increase was also found in the NE2 group compared with the UN group. These results suggest that $2 \%$ vitamin $\mathrm{E}$ had a neurotrophic effect on myenteric neurons normoglycemic rats as those presenting the clinical picture of DM.

The present study analyzed nitrergic neurons using the nNOS immunohistochemistry technique, which is used as a marker for the presence of nitric oxide (NO). We were able to determine nitrergic neuronal density using the nNOS immunohistochemistry technique ${ }^{(33)}$, which was similar for all groups. Similar results were found by Pereira et al. ${ }^{(22)}$ in the ileum of rats using the same experimental model. Other studies did not find significant results with regard to the number of nNOS-immunoreactive neurons in different segments of the gastrointestinal tract, such as stomach ${ }^{(14)}$, distal colon $^{(44)}$, and duodenum ${ }^{(13)}$. According to Pereira et al. ${ }^{(22)}$, this subpopulation of neurons is highly resistant to the action of free radicals produced by DM-induced hyperglycemia, explaining the results described above, including our study of enteric neurons.

A $44.2 \%$ increase in nitrergic neuron cell body area was observed in diabetic animals (UD group) compared with control animals (UN group). Several studies have observed similar results in the ileum ${ }^{(22,26,46)}$ and stomach ${ }^{(24)}$. According to Fregonesi et al. ${ }^{(14)}$, increased NADPH utilization occurs in DM because of the activation of the aldose reductase and glutathione reductase pathways, thus reducing the availability of this metabolic cofactor for the NOS enzyme. Therefore, increased activity of the pathway responsible for NO synthesis in nitrergic neurons may occur in an attempt to increase $\mathrm{NADPH}$, thus increasing cell volume. This hypothesis is supported by a radiochemical detection study by Shotton et al. ${ }^{(28)}$, who observed an increase in the activity of the nNOS enzyme in the ileum of rats with DM, and a Western 
blot study by Adeghate et al. ${ }^{(1)}$, who found increased nNOS expression in diabetic animals of the same species and sex used in the present study.

Importantly, nNOS protein expression also varies according to differences in the species and sex of animals. Surendran and Kondapaka ${ }^{(32)}$ found that using male and female mice yielded results contrary to those by Adeghate et al. ${ }^{(1)}$, Shotton et al. ${ }^{(27)}$, and the present study using male Wistar rats. According to Surendran and Kondapaka ${ }^{(32)}$, reduced $\mathrm{nNOS}$ expression occurs in male diabetic mice, whereas enzyme expression increased in female diabetics compared with control animals. Supplementation with vitamin E in the DE1 and DE2 groups did not significantly alter nitrergic neuron cell body area compared with the UD group.

\section{CONCLUSIONS}

We conclude that $2 \%$ vitamin E supplementation exerts a neurotrophic effect on myosin-V-immunoreactive myenteric neurons in normoglycemic and diabetic rats. However, the vitamin in both concentrations tested, do not shows neuroprotective effects on the on diabetes-induced enteric neuron loss in the jejunum.

\section{ACKNOWLEDGMENTS}

We appreciate the excellent technical support of Ana Paula de Santi Rampazzo, Maria Euride do Carmo Cancino and Maria dos Anjos Fortunato.

Tronchini EA, Trevizan AR, Tashima CM, Pereira RVF, Zanoni JN. Suplementação com vitamina E 0,1\% e 2\% em ratos diabéticos: análise de neurônios mioentéricos imunomarcados para miosina-V e nNOS no jejuno. Arq Gastroenterol. 2012;49(4):284-90.

RESUMO - Contexto - O diabetes mellitus (DM) é uma doença caracterizada pela hiperglicemia que a longo prazo, quando não tratada, desenvolve complicações vasculares e neurológicas, responsáveis pelo desenvolvimento das alterações no sistema nervoso entérico de pacientes diabéticos. Em nível gastrointestinal o DM provoca modificações motoras, sensoriais e na função reflexa desse sistema, podendo ocasionar gastroparesia, diarreia, constipação, megacólon, lentidão do trânsito gastrointestinal, estase e dilatação gástrica com diminuição ou aumento de contrações peristálticas. Diversos estudos têm evidenciado que o estresse oxidativo é o principal responsável pelas complicações vasculares e neurológicas que atingem o sistema nervoso entérico de diabéticos. Objetivo - O efeito da vitamina E 0,1\% e 2 sobre a miosina-V e nNOS imunorreativas em neurônios do jejuno de ratos diabéticos foram investigados. Métodos - Trinta ratos foram divididos em grupos: normoglicêmicos (NU), normoglicêmicos tratados com vitamina E $0,1 \%$ (NE1), normoglicêmicos tratados com vitamina E 2\% (NE2), diabético (UD), diabéticos tratados com vitamina E 0,1\% (DE1), e diabéticos tratados com vitamina E 2\% (DE2). A densidade neuronal e áreas de corpos celulares de neurônios foram determinadas. Resultados - Diabetes (UD grupo) reduziu significativamente o número de neurônios miosina-V imunorreativos quando comparado com o grupo UN. Os grupos DE1 e DE2 não exibem uma maior densidade do que o grupo $\mathrm{D}(P>0,05)$. Densidade nitrérgicos não se alterou com diabetes $(P>0,05)$. As áreas dos neurônios miosina-V e nNOS imunorreativos aumentaram significativamente nos grupos NE2 e UD comparados com o grupo UN. Conclusãa - A suplementação com vitamina E 2\% teve um efeito neurotrófico apenas na área da miosina-V imunorreativos neurônios em comparação com o grupo UD.

DESCRITORES - Vitamina E. Diabetes mellitus experimental. Jejuno. Neurônios. Miosina tipo V. Óxido nítrico sintase. Ratos. 


\section{REFERENCES}

1. Adeghate E, al-Ramadi B, Saleh AM, Vijayarasathy C, Ponery AS, Arafat K, Howarth FC, El-Sharkawy T. Increase in neuronal nitric oxide synthase content of the gastroduodenal tract of diabetic rats. Cell Mol Life Sci. 2003;60:1172-9.

2. Afzaal S, Singh M, Saleem I. Aetipathogenesis and management of diabetic neuropathy. J Assoc Physicians India. 2002;50:707-11.

3. Alves AM, Alves EP, Fregonesi CET, Defani MA, Stabille SR, Evangelista CC, dos Santos CA, de Miranda-Neto MH. Morphoquantitative aspects of NADH-diaphorase myenteric neurons in the ileum of diabetic rats treated with acetyl-L-carnitine. Anat Histol Embryol. 2006;35:13-8.

4. Belai A, Lincoln J, Milner P, Burnstock G. Progressive changes in adrenergic, serotonergic, and peptidergic nerves in proximal colon of streptozotocin-diabetic rats. Gastroenterology. 1988;95:1234-41

5. Belai A, Lincoln J, Milner P, Burnstock G. Differential effect of streptozotocin-induced diabetes on the innervations of the ileum and distal colon. Gastroenterology. 1991;100:1024-32.

6. Bergmeyer HE, Bernet E. D-glucose determination with glucose oxidase and peroxidase. In: Bergmeyer HU, Gawehn K, editors. Methods of enzymatic analysis 2nd ed. New York: Academic Press; 1974. p.1205-15.

7. Brownlee M. Biochemistry and molecular cell biology of diabetic complications. Nature. 2001;414:813-20.

8. Bytzer P, Talley NJ, Leemon M, Young LJ, Jones MP, Horowitz M. Prevalence of gastrointestinal symptoms associated with diabetes mellitus: a population-based survey of 15,000 adults. Arch Intern Med. 2001;161:1989-96.

9. Chandrasekharan B, Srinivasan S. Diabetes and the enteric nervous system. Neurogastroenterol Motil. 2007;19:951-60.

10. Cheney RE, O'Shea MK, Heuser JE, Coelho MV, Wolenski JS, Espreafico EM, Forscher P, Larson RE, Mooseker MS. Brain myosin-V is a two-headed unconventional myosin with motor activity. Cell. 1993;75:13-23.

11. Cotter MA, Love A, Watt MJ, Cameron NE, Dines KC. Effects of natural free radical scanvengers on peripheral nerve and neurovascular function in diabetic rats. Diabetologia. 1995;38:1285-94

12. de Freitas P, Natali MRM, Pereira RV, de Miranda-Neto MH, Zanoni JN. Myenteric neurons and intestinal mucosa of diabetic rats after ascorbic acid supplementation. World J Gastroenterol. 2008;14:6518-24.

13. de Mello ST, de Miranda-Neto MH, Zanoni JN, Furlan MM. Effects of insulin treatment on $\mathrm{HuC} / \mathrm{HuD}$, NADH diaphorase, and nNOS-positive myoenteric neurons of the duodenum of adult rats with acute diabetes. Dig Dis Sci. 2009;54:731-7.

14. Fregonesi CE, Molinari SL, Alves AM, Defani MA, Zanoni JN, Bazotte RB, de Miranda-Neto MH. Morphoquantitative aspects of nitrergic myoenteric neurons from the stomach of diabetic rats supplemented with acetyl-L-carnitine. Anat Histol Embryol. 2005;34:93-7.

15. Furlan MM, Molinari SL, de Miranda-Neto MH. Morphoquantitative effects of acute diabetes on the myenteric neurons of the proximal colon of adult rats. Arq Neuropsiquiatr. 2002;60:576-81.

16. Furness JB, Costa M. The enteric nervous system. New York: Churchill Livingstone; 1987.

17. Guyton AC, Hall EJ. Tratado de fisiologia médica. $9^{\mathrm{a}}$ ed. Rio de Janeiro: Guanabara Koogan; 1997.

18. Koenig RJ, Peterson CM, Jones RL, Saudek C, Lehrman M, Cerami A. Correlation of glucose relation and hemoglobin AIc in diabetes mellitus. N Engl J Med. 1976;295:417-20

19. Kuyvenhoven JP, Meinders AE. Oxidative stress and diabetes mellitus pathogenesis of long-term complications. Eur J Intern Med. 1999;10:9-19.

20. McLaren HE. Diabetic neuropathy. Compr Ther. 1978;4:54-8.

21. McLean IW, Nakane PK. Periodate-lysine-paraformaldehyde fixative: a new version for immunoelectron microscopy. J Histochem Cytochem. 1974;22:1077-83.

22. Pereira RV, de Miranda-Neto MH, da Silva Souza ID, Zanoni JN. Vitamin E supplementation in rats with experimental diabetes mellitus: analysis of myosin-V and nNOS immunoreactive myenteric neurons from terminal ileum. J Mol Histol. 2008;39:595-603
23. Rask-Madsen C, King GL. Mechanims of disease: endothelial dysfunction in insulin resistance and diabetes. Nat Clin Pract Endocrinol Metab. 2007:3:46-56.

24. Roldi LP, Pereira RV, Tronchini AE, Rizo GV, Scoaris CR, Zanoni JN, Natali MR. Vitamin E (a-tocopherol) supplementation in diabetic rats: effects on the proximal colon. BMC Gastroenterol. 2009;9:88.

25. Schoffen JPF, Soares A, de Freitas P, Buttow NC, Natali MR. Effects of a hypoproteic diet on myosin-V immunostained myenteric neurons and the proximal colon wall of aging rats. Auton Neurosci. 2005;122:77-83.

26. Shotton HR, Clarke S, Lincoln J. The effectiveness of treatments of diabetic autonomic neuropathy is not the same in autonomic nerves supplying different organs. Diabetes. 2003;52:157-64.

27. Shotton HR, Lincoln J. Diabetes only affects nitric oxide synthase-containing myenteric neurons that do not contain heme oxygenase 2. Brain Res. 2006;1068:248-56.

28. Shotton HR, Adams A, Lincoln J. Effect of aminoguanidine treatment on diabetes-induced changes in myenteric plexus of rat ileum. Auton Neurosci. 2007;132:16-26.

29. Singh R, Barden A, Mori T, Beilin L. Advanced glycation end-products: a review. Diabetologia. 2001;44:129-46.

30. Son SM. Role of vascular reactive oxygen species in development of vascular abnormalities in diabetes. Diabetes Res Clin Pract. 2007;77:s65-s70.

31. Surai PF. Vitamin E in avian reproduction. Poultry Avian Biol Rev. 1999;10:1-60

32. Surendran S, Kondapaka SB. Altered expression of neuronal nitric oxide synthase in the duodenum longitudinal muscle-myenteric plexus of obesity induced diabetes mouse: implications on enteric neurodegeneration. Biochem Biophys Res Comm. 2005;338:919-22.

33. Takahashi T. Pathophysiological significance of neuronal nitric oxide synthase in the gastrointestinal tract. J Gastroenterol. 2003;38:421-30.

34. Tashima CM, Tronchini EA, Pereira RV, Bazotte RB, Zanoni JN. Diabetic rats supplemented with L-glutamine: a study of immunoreactive myosin-V myenteric neurons and the proximal colonic mucosal. Dig Dis Sci. 2007;52:1233-41.

35. Tomlinson DR, Gardiner NJ. Glucose neurotoxicity. Nat Rev Neurosci. 2008;9:36-45.

36. Traber MG. Vitamin E regulatory mechanisms. Annu Rev Nutr. 2007;27:347-62

37. Valko M, Leibfritz D, Moncol J, Cronin MT, Mazur M, Telser J. Free radicals and antioxidants in normal physiological functions and human disease. Int $\mathrm{J}$ Biochem Cell Biol. 2007;39:44-84

38. Van Dam PS, Van Asbeck BS, Bravenboer B, Van Oirschot JF, Gispen WH, Marx JJ. Nerve function and oxidative stress in diabetic and vitamin E-deficient rats. Free Radic Biol Med. 1997;24:18-26.

39. Vincent AM, Feldman EL. New insights into the mechanisms of diabetic neuropathy. Rev Endocr Metab Disord. 2004;5:227-36.

40. Vincent AM, Russel JW, Low P, Feldman EL. Oxidative stress in the pathogenesis of diabetic neuropathy. Endocr Rev. 2004:25:612-28.

41. Vinik AI. Diabetic neuropathy: pathogenesis and therapy. Am J Med 1999;107(2B):17s-26s.

42. Vinik AI, Freeman R, Erbas T. Diabetic autonomic neuropathy. Semin Neurol. 2003;23:365-72.

43. Wang X, Quinn PJ. Vitamin E and its function in membranes. Prog Lipid Res 1999;38:309-36.

44. Yoneda S, Kadowaki M, Kuramoto H, Fukui H, Takaki M. Enhanced colonic peristalsis by impairment of nitrergic enteric neurons in spontaneously diabetic rats. Auton Neurosci. 2001;92:65-71.

45. Yoshida M, Kimura H, Kyuki K, Ito M. Effect of combined vitamin E and insulin administration on renal damage in diabetic rats fed a high cholesterol diet. Biol Pharm Bull. 2005;28:2080-6.

46. Zanoni JN, Buttow NC, Bazotte RB, de Miranda-Neto MH. Evaluation of the population of NADPH-diaphorase-stained and myosin- $\mathrm{V}$ myenteric neurons in the ileum of chronically streptozotocin-diabetic rats treated with ascorbic acid Auton Neurosci. 2003;104:32-8. 